\title{
Beneficial Environmentally Usage of Water Hyacinth: A Mini Review
}

\author{
Rezania $\mathrm{S}^{1,2}$, Md Din $\mathrm{MF}^{1,2 *}$, Mat Taib $\mathrm{S}^{2}$, Ling Yong $\mathrm{E}^{1,2}$, Chelliapan $\mathrm{S}^{3}$ and Kamyab $\mathrm{H}^{3}$ \\ ${ }^{1}$ Research Institute for Environmental Sustainability, UniversitiTeknologi Malaysia, Malaysia \\ ${ }^{2}$ Department of Environmental Engineering, UniversitiTeknologi Malaysia, Malaysia \\ ${ }^{3}$ Department of Engineering, UniversitiTeknologi Malaysia, Malaysia
}

Submission: March 22, 2017; Published: June 19, 2017

*Corresponding author: Md Din MF, Research Institute for Environmental Sustainability, Universiti Teknologi Malaysia, Email: mfadhil@utm.my

\begin{abstract}
Invasive species are a global threat to biological diversity and ecosystem functioning. Management of most aquatic plant species depends on properly identifying the desirable or nuisance plant. For instance, if eradication of this notorious weed is not possible, then the feasibility of using this plant as an alternative energy resource e.g. bioethanol and briquette can be considered. As aquatic plants do not compete with land resources used in arable food crop cultivation and thus are an incentive factor when it comes to biofuels production. Therefore, this review presents the major application of water hyacinth such as phyto remediation and bio energy production.
\end{abstract}

Keywords: Aquatic plants; Application; Phyto remediation; Bio energy production

\section{Introduction}

Aquatic plants growing in ponds and lakes are beneficial for fish and wildlife. Although invasive aquatic plants havelong been regarded as an intriguing potential feedstock because of their high growth rate in natural water bodies, most contemporary management is based on plant control rather than utilization [1]. For instance, large scale utilization of the water hyacinth species can serve as a positive approach to control, especially in the developing countries. The controlling mechanisms have had an important impact in controlling the spread of water hyacinth [2]. Malik [3], showed a remarkable approach towards the controlling and eradication of water hyacinth growth along with the combination of herbicidal control, integrated bio logical control and watershed management controlling nutrient supply. Overall, when considering the social and environmental benefits, the frameworks can possibly provide better socio-economic returns [2].

There are few recommendations to utilize harvested invasive aquatic plants for fertilizer, compost, paper-making, fuel production and other, as reported in many publications a decade ago. The possibility that any demonstration of value for invasive aquatic plants could have the perverse effect of speeding their spread [4]. Then, aquatic plants and manures are intrinsically high-moisture materials and as such, are more suited to 'wet' processing techniques [5]. In addition to the desire for controlling overgrowth, a primary rationale for attempting to utilize such plants is that they often show primary productivity rates significantly higher than terrestrial bio energy feedstock candidates [6]. For example, water hyacinths have been shown to produce annual crop yields of 100 dry tons per hectare in natural lakes [7]. By way of comparison, the highest trial yields obtained for switchgrass in the USA are in the order of 25 dry tons per hectare [8]. The rapid emergence of the bioenergy economy would seem to provide a clear opportunity for implementation of programs that can direct the productivity of aquatic plants into beneficial uses.

\section{Phyto Remediation}

Water hyacinth (E. crassipes), a rooted saprophyte, is a member of the pickerel weed family: Pontederiaceae, and Genus: Eichhornia [9]. It can accumulate high rate of metals due to quickly adaptation to different aquatic physicochemical conditions [10]. Recently, Rezania et al. [11], reviewed that the water hyacinth $(\mathrm{WH})$ is capable of assimilating large quantities of pollutants (heavy metals) and nutrients, which makes it effective in wastewater treatment. Hence, the removal uptake of nutrients by water hyacinth is highly related to its optimum growth rate [12,13]. As indicated by Zheng et al. [14], Eichhorniacrassipes was effective in removal of heavy metals and can tolerate high concentrations of heavy metal and can survive in extreme conditions too. As documented by Kay et al. [15], the metal accumulations within plant tissues of water hyacinth was in the order leaves $<$ stems $<$ roots. 


\section{Recent Advances in Petrochemical Science}

\section{Energy production}

As aquatic plants do not compete with land resources used in arable food crop cultivation and thus are an incentive factor when it comes to bio fuel production. Rezania et al. [16] found that some of the aquatic plants like water hyacinth can also be used for the production of biofuels. There are several advantages in the production of ethanol in comparison with gasoline, namely the utilization of an abundant and cheap source of renewable resources, reduction in greenhouse gas emission and benefits for rural community and social aspect of sustainability [17]. The possibility of water hyacinth conversion to the briquettes evaluated since two decades, which reviewed recently by Rezania et al. [16]. In another study, Rezania et al. [18] have reported that dried water hyacinth can use for manufacturing briquette, which is used for co-firing in coal power plant.

Water hyacinth is lignocellulosic and in its structure has monosaccharide and polysaccharide which contain different types of sugars and starch [16]. On the other hand, high contents of cellulose and hemicellulose with low lignin, impressive growth rate and no competition on land use made this plant as suitable lignocellulosic material for bio energy generation [19]. The high efficiency conversion of lignocelluloses such as WH to fuel ethanol usually comprises three major steps: pretreatment for breaking down the lignocellulosic structure, enzymatic hydrolysis to produce fermentable sugars, and microbial fermentation for ethanol yield [20].

In terms of combustion characteristic, water hyacinth briquette showed higher calorific value in comparison to the mangrove and firewood [21]. However, the value is still lower than the calorific value of charcoal. The mixing of fuel briquettes clearly demonstrated that water hyacinth based briquettes promised a potential of alternative to firewood and charcoal. Besides, Rodrigues et al. [22] proved that the water hyacinth briquette has greater amount of moisture content, similar amount of volatile matter and much greater ash content compared to the local wood fuel. In a study by Rezania et al. [18], the results showed that by increasing in WH percentage in bio-briquette, $\mathrm{O}_{2}$ and $\mathrm{CO}$ level decreased, whereas, that of $\mathrm{CO}_{2}$ and $\mathrm{NO}, \mathrm{NO}_{2}$ and $\mathrm{SO}_{2}$ were increased. Therefore, the results conclude that the WH: EFB biomass bio-briquette could be a great potential as an alternative source to conventional coal.

\section{Conclusion}

Water hyacinth is known as multifunctional plant since 50 years ago. This paper showed the potential application of this plant. Although, several researches should be carried out for the conversion of $\mathrm{WH}$ - waste to wealth that leading to a sustainable management of this plant [23]. In the other point of view, the feasibility of using hyacinth for various applications have been done as an academic interest, and there is no based products or technologies which are currently available on the market [24]. Therefore, for future studies, the implication of large scale utilization of water hyacinth for mentioned products in potential market is recommended.

\section{References}

1. Wilkie AC, Evans JM (2010) Aquatic plants: an opportunity feedstock in the age of BioEnergy. Biofuels 1(2): 311-321.

2. Güereña D, Neufeldt H, Berazneva J, Duby S (2015) Water hyacinth control in Lake Victoria: Transforming an ecological catastrophe into economic, social, and environmental benefits. Sustainable Production and Consumption 3: 59-69.

3. Malik A (2007) Environmental challenge vis a vis opportunity: the case of water hyacinth. Environ Int 33(1): 122-138.

4. Wilkie AC, Evans JM (2010) Aquatic plants: an opportunity feedstock in the age of bio energy. Biofuels 1(2): 311-321.

5. McKendry $P$ (2002) Energy production from biomass (part 1): overview of biomass. Bioresour Technol 83(1): 37-46.

6. Nigam JN (2002) Bioconversion of water-hyacinth (Eichhornia crassipes) hemicellulose acid hydrolyzates to motor fuel ethanol by xylose-fermenting yeast. J Biotechnol 97(2): 107-116.

7. Hronich JE, Martin L, Plawsky J, Bungay HR (2008) Potential of Eichhorniacrassipes for biomass refining. Journal of industrial microbiology \& biotechnology 35(5): 393-402.

8. Bransby DI, McLaughlin SB, Parrish DJ (1998) A reviews of carbon and nitrogen balances in switchgrass grown for energy. Biomass and Bioenergy 14(4): 379-384.

9. Dhote S, Dixit S (2009) Water quality improvement through macrophysics-a review. Environ Monit Assess 152(1-4): 149-153.

10. Liao SW, Chang WL (2004) Heavy metal phyto remediation by water hyacinth at constructed wetlands in Taiwan. Photogram Eng Remote Sensing 54: 177-185.

11. Rezania S, Ponraj M, Talaiekhozani A, Mohamad SE, Din MFM, et al. (2015) Perspectives of phyto remediation using water hyacinth for removal of heavy metals, organic and inorganic pollutants in wastewater. Journal of environmental management 163: 125-133.

12. Rezania S, Ponraj M, Fadhil Md Din M, Chelliapan S, MdSairan F, et al. (2016) Effectiveness of Eichhorniacrassipes in nutrient removal from domestic wastewater based on its optimal growth rate. Desalination and Water Treatment 57(1): 360-365.

13. Rezania S, Din MFM, Taib SM, Dahalan FA, Songip AR, et al. (2016) The efficient role of aquatic plant (water hyacinth) in treating domestic wastewater in continuous system. Int J Phyto remediation 18(7): 679685.

14. Zheng JC, Feng HM, Lam MHW, Lam PKS, Ding YW, et al. (2009) Removal of $\mathrm{Cu}$ (II) in aqueous media by bio sorption using water hyacinth roots as a bio sorbent material. Journal of hazardous materials 171(1): 780785 .

15. Kay SH, Haller WT, Garrard LA (1984) Effects of heavy metals on water hyacinths (Eichhorniacrassipes (Mart.) Solms). Aquatic Toxicology 5(2): 117-128.

16. Rezania S, Din MFM, Mohamad SE, Sohaili J, Taib SM, et al. (2017) Review on pretreatment methods and ethanol production from cellulosic water hyacinth. Bioresource 12(1): 2108-2124.

17. Lin Y, Tanaka S (2006) Ethanol fermentation from biomass resources: current state and prospects. Appl Microbiol Biotechnol 69(6): 627-642.

18. Rezania S, Din MFM, Kamaruddin SF, Taib SM, Singh L, et al. (2016) Evaluation of water hyacinth (Eichhorniacrassipes) as a potential raw material source for briquette production. Energy 111: 768-773. 
19. Phitsuwan P, Sakka K, Ratanakhanokchai K (2013) Improvement of lignocellulosic biomass in planta: a review of feed stocks, biomass recalcitrance, and strategic manipulation of ideal plants designed for ethanol production and process ability. Biomass and Bioenergy 58: 390-405.

20. Uday USP, Choudhury P, Bandyopadhyay TK, Bhunia B (2016) Classification, mode of action and production strategy of xylonite and its application for bio fuel production from water hyacinth. Int J Biol Macromol 82: 1041-1054.

21. Davies RM, Davies OA, Mohammed US (2013) Combustion characteristics of traditional energy sources and water hyacinth briquettes. International Journal of Scientific Research in Environmental Sciences, 1(7): 144-151.
22. Rodrigues AJ, Odero MO, Hayombe PO, Akuno W, Kerich D, et al. (2014) Converting water hyacinth to briquettes: a beach community based approach. Int J Sci: Basic Appl Res (IJSBAR) 15(1): 358-78.

23. Sindhu R, Binod P, Pandey A, Madhavan A, Alphonsa JA, et al. (2017) Water hyacinth a potential source for value addition: an overview. Bioresour Technol 230: 152-162.

24. Guna VK, Ilangovan M, Gangadharaiah AM, Reddy N (2017) Water Hyacinth: A Unique Source for Sustainable Materials and Products. ACS Sustainable Chemistry \& Engineering 5(6): 4478-4490.

\section{Your next submission with Juniper Publishers will reach you the below assets}

- Quality Editorial service

- Swift Peer Review

- Reprints availability

- E-prints Service

- Manuscript Podcast for convenient understanding

- Global attainment for your research

- Manuscript accessibility in different formats

( Pdf, E-pub, Full Text, Audio)

- Unceasing customer service

Track the below URL for one-step submission https://juniperpublishers.com/online-submission.php 